Faco, R.A.; Sola. F. Responsabilidade socioambiental como valor agregado a serviços de Ecoturismo e Educação Ambiental no terceiro setor. Anais do VIII Congresso Nacional de Ecoturismo e do IV Encontro Interdisciplinar de Ecoturismo em Unidades de Conservação. Revista Brasileira de Ecoturismo, São Paulo, v.4, n.4, 2011, p. 567.

\title{
RESPONSABILIDADE SOCIOAMBIENTAL COMO VALOR AGREGADO A SERVIÇOS DE ECOTURISMO E EDUCAÇÃO AMBIENTAL NO TERCEIRO SETOR
}

\author{
Regiane Avena Faco*, Fernanda Sola* \\ Universidade Federal de São Carlos - Câmpus Sorocaba \\ E-mails: regiane.avena@yahoo.com.br, fernandasola@usp.br
}

A atual preocupação com a escassez dos recursos naturais num horizonte não muito distante, despertou na sociedade a busca por alternativas que consigam conciliar desenvolvimento e a conservação ambiental. Esse novo contexto tem gerado uma série de ações em vários setores da economia, sendo que no ambiente organizacional, pode-se pontuar iniciativas nessa direção através da chamada, responsabilidade social, e também, especificamente da responsabilidade socioambiental. Como uma forma de compreender o Ecoturismo, faz-se necessário entender, primeiramente, o próprio Turismo e como o seu desenvolvimento desencadeou novas formas de abordagens para que seja possível analisar e compreender as práticas de mercado liberais e as que buscam atingir um consumidor diferenciado. É possível encontrar práticas responsáveis no segmento? O ecoturismo, como segmento do turismo é dependente do oferecimento de um conjunto de serviços, e, assim, demanda para sua execução a oferta de serviços tais como: hotéis, restaurantes, guias de turismo, transporte, entre outros, quase essencialmente, advindos da iniciativa privada. O que se coloca é se esse segmento do turismo apóia a execução em preceitos bem distintos tais como: a conservação ambiental, educação ambiental e benefícios as comunidades receptoras, por que não incluir as comunidades tradicionais em processos antes dominados pelos empreendedores de fora? E ainda, por que não incluir essas comunidades numa atividade responsável e conscientizadora em relação aos aspectos da conservação do meio ambiente, garantindo a interação do ser humano com o meio ambiente, por meio da relação vivencial e construindo assim uma reflexão sobre o correto uso dos recursos naturais, através da educação ambiental, devendo ser, portanto, por si próprio uma atividade dotada de um comportamento ético e responsável? O que se observa na pratica é que poucas são as iniciativas nesse sentido, sendo que o melhor desenvolvimento da atividade, ou o mais próximo do que se espera que ela seja se dá quando realizado através do envolvimento do terceiro setor, representado aqui pelas organizações não governamentais, surgidas principalmente do despertar do movimento ambientalista. As organizações não governamentais (ONGs) podem ser vistas como grandes atores sociais desse movimento em prol da responsabilidade socioambiental, e acabam hoje, portanto, exercendo grande pressão no primeiro setor em busca de uma nova postura organizacional, bem como, atuando junto a algumas empresas nos mais diversos setores da economia, não sendo diferente com o turismo. Assim, temos que as ONGs se apresentam como entidades mais adequadas diante do planejamento e execução de atividades de Ecoturismo e que, portanto, possuem maior confiabilidade diante da contratação de serviços para tal do que empresas do setor privado, em diversas etapas da gestão da atividade, sendo na capacitação, na criação de diretrizes, no planejamento, bem como na execução.

Palavras-chave: Responsabilidade Socioambiental; Ecoturismo; ONGs 